\title{
THERMAL COMFORT IN REDUCED MODELS OF BROILERS' HOUSES, UNDER DIFFERENT TYPES OF ROOFING MATERIALS
}

\author{
EDUARDO A. DE ALMEIDA ${ }^{1}$, ROBERTA PASSINI ${ }^{2}$
}

\begin{abstract}
The research was developed to evaluate the use of different types of roofing materials regularly used in poultry houses. Measurements of thermal comfort were made through the use of techniques such as the Black Globe and Humidity Index (BGHI), the Thermal Heat Load (THL) and Enthalpy (H). Conducted in the State University of Goiás, during the months of April and May, 2011, the experiment was composed of five different treatments: AC - Asbestos cement tiles, BA - Bamboo tiles, BAP - Bamboo tiles painted in white, FB - Vegetable fiber tiles and bitumen, FBP - Vegetable fiber tiles and bitumen painted in white. The experiment consisted in 15 repetitions, which were considered the different days of measurements taken. Throughout the studied period, the time of the day considered the least comfortable was the one observed at $2: 00 \mathrm{pm}$, and the coverage of vegetable fiber and bitumen showed the highest value of BGHI (84.1) when compared to other types of coverage, characterizing a situation of lower thermal comfort, and no difference was found for THL and $\mathrm{H}$ on treatments in the studied region.
\end{abstract}

KEYWORDS: ambience, alternative roofing material, poultry production.

\section{CONFORTO TÉRMICO EM MODELOS REDUZIDOS DE GALPÕES PARA FRANGOS DE CORTE, UTILIZANDO-SE DE DIFERENTES TIPOS DE COBERTURAS}

RESUMO: Esta pesquisa foi conduzida com o objetivo de avaliar diferentes tipos de coberturas em instalações para aves, por meio do Índice de Temperatura de Globo Negro e Umidade (ITGU), Carga Térmica de Radiação (CTR) e Entalpia (H). O experimento foi conduzido na Universidade Estadual de Goiás, entre os meses de abril e maio de 2011, sendo composto por cinco tratamentos (coberturas): CA - Telha de cimento-amianto; BA - Telha de bambu; BAP - Telha de bambu pintada de branco; FB - Telha de fibra vegetal e betume; FBP - Telha de fibra vegetal e betume pintada de branco, com 15 repetições, sendo as repetições os dias de medição. Dentre os horários estudados, o considerado menos confortável foi às $14 \mathrm{~h}$, sendo que a cobertura de fibra vegetal e betume foi a que apresentou maior valor de ITGU $(84,1)$ quando comparada às demais coberturas, caracterizando uma situação de menor conforto térmico, não sendo observada diferença para CTR e $\mathrm{H}$ entre os tratamentos na região estudada.

PALAVRAS-CHAVE: ambiência, telhas alternativas, avicultura.

\section{INTRODUCTION}

In tropical countries, like Brazil, the main limiting factors for the welfare of the birds and for achieving high productivity are environmental factors, which include high temperatures and high humidity within the facilities, causing stress to the animal and, thus, decreased production (SOUSA, 2005).

The facility must promote a comfortable environment to the animal, without requiring the expenditure of energy conservation or heat dissipation. In this situation, the animal is within the thermal comfort zone (BAÊTA \& SOUZA, 2010), allowing the expression of its maximum yield potential, resulting in higher production (NAZARENO et al., 2009).

\footnotetext{
${ }^{1}$ Mestrando em Zootecnia, Bolsista de Iniciação Científica, PIBIC/CNPq, Universidade Estadual Paulista, FCAV/UNESP, Jaboticabal - SP, eng.eduardoalves@ hotmail.com.

${ }^{2}$ Doutora em Zootecnia, Pós-doutora em Produção Animal, Universidade Estadual de Goiás, Curso de Engenharia Agrícola.

Recebido pelo Conselho Editorial em: 4-7-2011
}

Aprovado pelo Conselho Editorial em: 11-9-2012 
The roofs are responsible for promoting a more appropriate environment to livestock production, providing a significant reduction in the Thermal Heat Load compared to the one received by the animal outdoors (BAÊTA \& SOUZA, 2010). According to CONCEIÇÃO et al. (2008), many of the facilities use corrugated tiles, such as asbestos cement, for presenting lower cost than ceramic tiles. Furthermore, the construction is faster, easier to clean, which explains the preference of such cover (TCPO, 2008).

In industrialized countries, asbestos has been banned from civil construction because it is harmful to health, favoring the use of natural fibers in materials that previously used asbestos as a raw material (PICANÇO \& GHAVAMI, 2008).

The comfort parameters encompass in a single value, the combined effect of the meteorological elements and the built environment on the individual studied (OLIVEIRA et al., 2006). Among the most commonly used comfort parameters, we find the Thermal Heat Load (FIORELLI et al., 2010; ABREU et al., 2009; ROCHA et al., 2010), Black Globe and Humidity Index (NAZARENO et al., 2011) and Enthalpy (BARBOSA FILHO et al., 2007).

The use of reduced models for the evaluation of the thermal behavior of designs has several advantages, such as low material and labor cost and time involved. Another important factor is the ability to improve the product, since any change to improve the design performance may be realized more easily (JENTZSCH, 2002).

This research aimed to study the thermal performance of alternative roofs in reduced models of poultry houses, trying to find values that may encourage the use of these materials, promoting thermal comfort allied to sustainability.

\section{MATERIAL AND METHODS}

The experiment was conducted at the State University of Goiás, University Unity for Science and Technology (UnUCET), Anápolis, state of Goiás (GO), Brazil, during the months of April and May, 2011. The municipality is at latitude $16^{\circ} 22^{\prime} 56,76^{\prime \prime} \mathrm{S}$ and longitude $48^{\circ} 56^{\prime} 45,46^{\prime \prime} \mathrm{W}$, and it is about $1.017 \mathrm{~m}$ above sea level. The climatic classification of the municipality, according to Koeppen, is Aw (Tropical Wet), with two defined seasons: a dry season, characterized by a colder period which extends from May to September; and a wet season, characterized by a hotter period which extends from October to April.

Meteorological data from the period of the experiment were obtained from a meteorological station located approximately 20 meters from the experimental area. During the experimental period, it was observed the following values in the region: mean wind speed: $5.5 \mathrm{~m} \mathrm{~s}^{-1}$; mean relative humidity: $68 \%$; mean air temperature: $21.2^{\circ} \mathrm{C}$.

The experimental design was a completely randomized (CRD), which used five reduced models of poultry houses, where each model randomly received a different type of roof, where dry bulb temperature $\left(\mathrm{T}_{\mathrm{db}}\right)$, black globe temperature $\left(\mathrm{T}_{\mathrm{bg}}\right)$, relative humidity $(\mathrm{RH})$ and wind speed (WS) were collected at 08:00 am, 10:00 am, 12:00 pm, 2:00 pm, 4:00 pm and 6:00 pm, for 15 nonconsecutive days, considering the collection day as repetition.

The reduced models were constructed in masonry, distorted in scale with dimensions of $1.5 \mathrm{~m}$ x $1.0 \mathrm{~m} \mathrm{x} 1.0 \mathrm{~m}(\mathrm{~L} \mathrm{x} \mathrm{W} \mathrm{x} \mathrm{H})$, and only the east and west sides were closed, maintaining a spacing of $4 \mathrm{~m}$ between the models (Figure 1). According to JENTZCH (2002), the models in distorted scale may be used to evaluate thermal behavior in shelters, however, do not allow the use in the production system, because they do not have appropriate dimensions for animal livestock. For the construction of roofs, it was adopted a tilt of tiles of $25^{\circ}$, a value considered ideal according to VIGODERIS (2007), who recommends a roof inclination between $20^{\circ}$ and $30^{\circ}$ in poultry houses. 
To compose the treatments, it was used the following types of coverage: AC - asbestos cement tiles; BA - bamboo tile; BAP - bamboo tiles painted in white, FB - vegetable fiber tiles and bitumen; FBP - vegetable fiber tiles and bitumen painted in white.

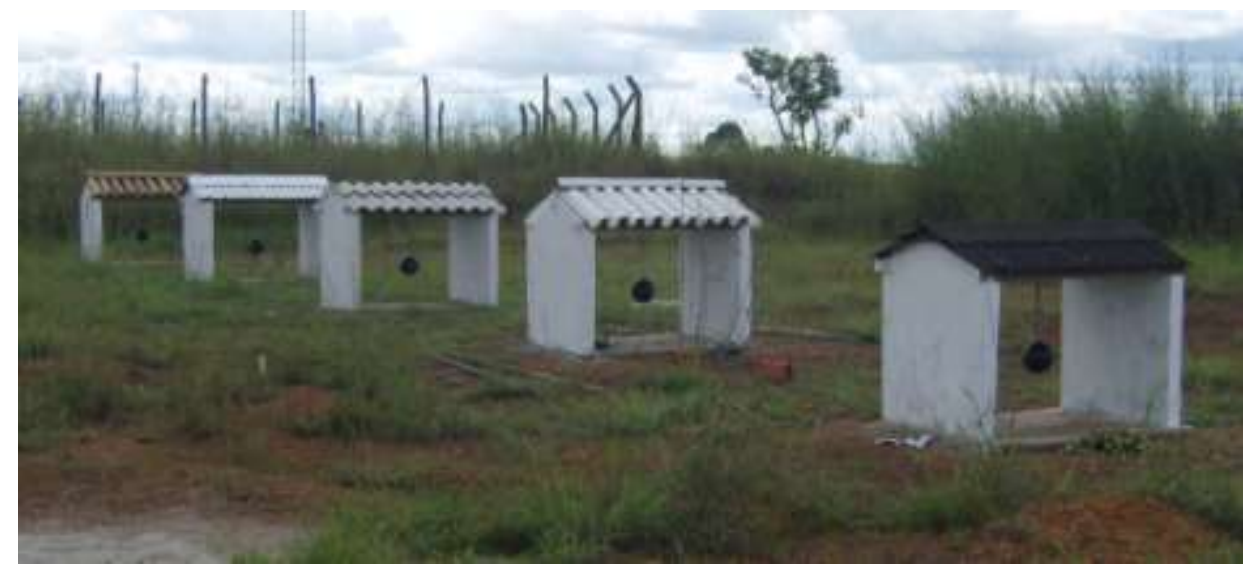

FIGURE 1. Reduced models with the respective roofing installed.

It was used asbestos cement tiles with a thickness of $5 \mathrm{~mm}$, which was installed in one of the shelters, in order to compare its performance with alternative covers.

To make the bamboo tiles, the giant bamboo was used (Dendrocalamus giganteus sp.). Bamboos were treated by immersion in solution of chromated copper borate at $3 \%$, and they remained submerged for 24 hours. After treatment, bamboos were cut in half so that, for each piece of bamboo, two grooves were formed. The grooves received holes for screw fixation of parts, thereby forming the tiles.

The vegetable fiber tiles and bitumen were purchased in a construction material store, and they were composed of vegetable fibers obtained by paper and cardboard recycling, and a paste was made with this product and the bitumen was added. The tiles were cut according to the size of the cover and were installed with the aid of staples, and, for the treatments composed by tiles with painting on the outer surface, it was used latex paint in ice white.

It was used a digital thermo-hygrometer of measuring scale of temperature ranging from $50{ }^{\circ} \mathrm{C}$ to $+70{ }^{\circ} \mathrm{C}$ at the internal sensor, and $-10{ }^{\circ} \mathrm{C}$ to $+70{ }^{\circ} \mathrm{C}$ at the external sensor (accuracy of $+/ 1{ }^{\circ} \mathrm{C}$ for temperature and $+/-2 \%$ for humidity). It was installed a thermo-hygrometer inside each reduced model and one on the external environment, collecting temperature and humidity throughout the day.

The black globes were made using PVC globes, of $0.20 \mathrm{~m}$ in diameter, and the external sensor of digital thermo-hygrometer was adapted in the center of the globe (accuracy of $+/-1{ }^{\circ} \mathrm{C}$ ), and the globes were painted with spray paint in matt black. According to SOUZA et al. (2002), different diameters of PVC globes may be used to replace the standard copper globe, since the values observed in globes made from this material have a good correlation with the values obtained by standard globe, enabling further reduction in the costs of equipment acquisition. The instruments were installed at the geometric center of the reduced model and at the external environment, at $0.3 \mathrm{~m}$ from the floor, corresponding to the center of mass of the birds (WELKER et al., 2008).

To obtain the air speed in different treatments and times, it was used a Hygro-thermoanemometer digital lux meter, LS8000 Model (accuracy $\pm 3 \%$ ), and the samples were collected within each shelter, at $30 \mathrm{~cm}$ from the floor, and at external area of reduced models at the same height.

The dew point temperature $\left(\mathrm{T}_{\mathrm{dp}}\right)$, wet bulb temperature $\left(\mathrm{T}_{\mathrm{wb}}\right)$, and enthalpy $(\mathrm{H})$ were obtained using the program Grapsi ${ }^{\circledR}$, developed by MELO et al. (2004). Data reported to the program were air temperature, relative humidity and altitude of the location. 
With the collected data, we calculated the Black Globe and Humidity Index (ITGU), Thermal Heat Load ( THL) and Enthalpy (H).

The BGHI was calculated by the equation developed by BUFFINGTON et al. (1977), which relates black globe temperature $\left(\mathrm{T}_{\mathrm{bg}}\right)$ and dew point temperature $\left(\mathrm{T}_{\mathrm{dp}}\right)$ :

$$
\mathrm{BGHI}=\mathrm{T}_{\mathrm{bg}}+0.36 \mathrm{~T}_{\mathrm{dp}}+41.5
$$

In which:

$\mathrm{T}_{\text {bg }}$ - black globe temperature, ${ }^{\circ} \mathrm{C}$, and

$\mathrm{T}_{\mathrm{dp}}$ - dew point temperature, ${ }^{\circ} \mathrm{C}$.

The Thermal Heat Load (THL) was calculated using the expression 2, proposed by ESMAY (1969), which expresses the total radiation received by the black globe of the environment around it.

$$
\mathrm{THL}=\sigma(\mathrm{MRT})^{4}
$$

In which:

$\sigma$ - Stefan-Boltzmann constant $\left(5.67 \times 10^{-8} \mathrm{~W} \mathrm{~m}^{-2} \mathrm{~K}^{-4}\right)$, and

MRT - mean radiant temperature, $\mathrm{K}$.

The Mean Radiant Temperature (MRT) is expressed by eq.(3):

$$
\mathrm{MTR}=100\left[2.51 . \mathrm{WS}^{1 / 2}\left(\mathrm{~T}_{\mathrm{bg}}-\mathrm{T}_{\mathrm{bs}}\right)+\left(\mathrm{T}_{\mathrm{bg}} / 100\right)^{4}\right]^{1 / 4}
$$

In which:

$\mathrm{T}_{\mathrm{bs}}$ - air temperature, $\mathrm{K}$, and

WS - wind speed, $\mathrm{m} \mathrm{s}^{-1}$.

For calculating the enthalpy $(\mathrm{H})$, it was used the computer program Grapsi ${ }^{\circledR}$, where air temperature, relative humidity, and altitude of the experimental area were entered as input values, and the enthalpy was obtained by correlating input values in equations which determine the psychrometric properties of the air.

Data were analyzed by analysis of variance and Skott-Knott test for comparison of means, at $1 \%$ of significance level, and were processed using the software SISVAR 5.1® (FERREIRA, 2008).

\section{RESULTS AND DISCUSSION}

There were significant differences $(\mathrm{P}<0.01)$ only between the external environment and treatments, with no significant difference observed between treatments for BGHI and THL (Table 1), and the highest values of BGHI and THL were found in the external environment. This fact may be explained by the lack of closure on the sides of the prototypes, making the heat exchange between the internal and the external environment occur rapidly, occurring in an equilibrium temperature inside shelters.

\begin{tabular}{|c|c|c|c|c|c|c|c|c|c|}
\hline \multirow{2}{*}{ Variable } & \multicolumn{6}{|c|}{ Treatments } & \multirow{2}{*}{ Mean } & \multirow{2}{*}{$\begin{array}{l}\text { C.V. } \\
(\%)\end{array}$} & \multirow{2}{*}{ Prob. $\mathrm{F}$} \\
\hline & $\mathrm{AC}$ & $\mathrm{BA}$ & BAP & FB & FBP & External & & & \\
\hline BGHI & $76.4 \mathrm{a}$ & $76.1 \mathrm{a}$ & $76.3 \mathrm{a}$ & $76.7 \mathrm{a}$ & $76.4 \mathrm{a}$ & $80.1 \mathrm{~b}$ & 77.0 & 3.14 & 0.001 \\
\hline THL (W.m²) & $525.6 \mathrm{a}$ & $520.6 \mathrm{a}$ & $522.8 \mathrm{a}$ & $523.6 \mathrm{a}$ & $526.1 \mathrm{a}$ & $596.4 \mathrm{~b}$ & 535.9 & 8.31 & 0.001 \\
\hline $\mathrm{H}\left(\mathrm{kJ} \mathrm{kg}^{-1}\right)$ & $55.4 \mathrm{a}$ & $55.0 \mathrm{a}$ & $55.4 \mathrm{a}$ & $56.1 \mathrm{a}$ & $55.0 \mathrm{a}$ & $57.6 \mathrm{~b}$ & 55.8 & 6.28 & 0.001 \\
\hline
\end{tabular}

TABLE 1. Daily mean values observed for the environmental variables and thermal indexes, with its respective coefficients of variation and statistical probabilities.

*Means followed by the same letter in the row do not differ statistically by Scott Knott test, at 1\% probability. 
The results are similar to those found by SARMENTO et al. (2005), who verified that reflective paint, when used alone, is not effective in reducing the thermal comfort indexes in the height of the mass center of birds. Other necessary environmental modifications which promote comfort animal are necessary.

The behavior of BGHI observed in this study differed from the behavior observed by NAZARENO et al. (2011), who found the lowest values of BGHI in the external environment in relation to other production systems. The fact that, in this study, the BGHI is superior at the external environment in relation to the BGHI inside the installations is because the coverage reduces the amount of heat passed to the atmosphere and because there is no presence of animals in the reduced models, and, therefore, there is no contribution of the animal in increasing the air temperature and relative humidity due to their metabolism.

For $\mathrm{H}$, there was a significant difference $(\mathrm{P}<0.01)$ only between treatments and the external environment, where the value of enthalpy out of the shelters was significantly higher than values found within them, with no significant difference between treatments. The enthalpy means remained within the thermal comfort zone for birds in the sixth week of life, which, according to BARBOSA FILHO et al. (2007), varies from 54.7 to $62.9 \mathrm{~kJ} \mathrm{~kg}^{-1}$ of dry air.

There were significant differences between the schedules for the different treatments $(\mathrm{P}<0.01)$, with the lowest values of $\mathrm{H}$ found at 8:00 am and 18:00 pm (Table 2).

TABLE 2. Mean values of $\mathrm{H}(\mathrm{kJ} / \mathrm{kg})$, in different treatments and times of collection.

\begin{tabular}{ccccccc}
\hline \multirow{2}{*}{ Treatments } & $8: 00 \mathrm{am}$ & $10: 00 \mathrm{am}$ & $12: 00 \mathrm{pm}$ & $2: 00 \mathrm{pm}$ & $4: 00 \mathrm{pm}$ & $6: 00 \mathrm{pm}$ \\
\cline { 2 - 7 } & $51.0 \mathrm{bA}$ & $58.4 \mathrm{dA}$ & $60.4 \mathrm{dA}$ & $61.4 \mathrm{dA}$ & $54.4 \mathrm{cA}$ & $46.7 \mathrm{aA}$ \\
AC & $50.1 \mathrm{bA}$ & $58.3 \mathrm{dA}$ & $59.5 \mathrm{dA}$ & $59.8 \mathrm{dA}$ & $56.3 \mathrm{cA}$ & $46.3 \mathrm{aA}$ \\
BA & $50.2 \mathrm{bA}$ & $57.9 \mathrm{cA}$ & $60.3 \mathrm{dA}$ & $60.1 \mathrm{dA}$ & $57.6 \mathrm{cB}$ & $46.6 \mathrm{aA}$ \\
BAP & $50.4 \mathrm{bA}$ & $58.1 \mathrm{cA}$ & $61.0 \mathrm{dA}$ & $62.0 \mathrm{dA}$ & $58.3 \mathrm{cB}$ & $46.8 \mathrm{aA}$ \\
FB & $50.7 \mathrm{bA}$ & $57.6 \mathrm{cA}$ & $59.8 \mathrm{dA}$ & $60.3 \mathrm{dA}$ & $55.5 \mathrm{cA}$ & $46.3 \mathrm{aA}$ \\
FBP & $58.2 \mathrm{bB}$ & $59.3 \mathrm{bA}$ & $60.1 \mathrm{bA}$ & $60.1 \mathrm{bA}$ & $58.3 \mathrm{bB}$ & $49.6 \mathrm{aB}$ \\
External &
\end{tabular}

AC - Asbestos cement tiles, BA - Bamboo tiles, BAP - Bamboo tiles painted in white, FB - Vegetable fiber tiles and bitumen, FBP Vegetable fiber tiles and bitumen painted in white, External - Environment outside the shelters. *Different lower case letters, at the rows, differ statistically by Scott Knott test, at $1 \%$ probability. **Different upper case letters, at the columns, differ statistically by Scott Knott test, at $1 \%$ probability.

It was observed significant difference between treatments $(\mathrm{P}<0.01)$ only at 4:00pm, where the highest values were found in $\mathrm{FB}\left(58.3 \mathrm{~kJ} \mathrm{~kg}^{-1}\right)$ and BAP $\left(57.6 \mathrm{~kJ} \mathrm{~kg}^{-1}\right)$, and these values are similar to the ones observed in the external area $\left(58.3 \mathrm{~kJ} \mathrm{~kg}^{-1}\right)$. At 8:00 am and 6:00 pm, enthalpy differed only between the external environment and treatments, and no significant difference was observed between treatments.

According to BARBOSA FILHO et al. (2007), birds raised in environments whose enthalpy is between 54.7 to $62.9 \mathrm{~kJ} \mathrm{~kg}^{-1}$ of dry air are in a state of thermal comfort. Therefore, in this study, for all treatments and at all times the enthalpy was within the limit of comfort for broilers, except for 6:00 pm, whose enthalpy value was relatively lower than the limit of comfort. The values of enthalpy in FB and $\mathrm{AC}$ treatments at 2:00 pm, despite not having deferred the other treatments, showed a value close to the upper limit of comfort for birds, which is $62.9 \mathrm{~kJ} \mathrm{~kg}^{-1}$ in the sixth week of life, making clear the lower efficiency of such coverage in the reduction of the enthalpy within a facility, characterizing a higher thermal discomfort.

There were significant differences $(\mathrm{P}<0.01)$ in the values of BGHI (Table 3$)$ for times in different treatments. 
TABLE 3. Mean values of BGHI, in different treatments and times of collection.

\begin{tabular}{ccccccc}
\hline \multirow{2}{*}{ Treatments } & \multicolumn{7}{c}{ Times } \\
\cline { 2 - 7 } & $8: 00 \mathrm{am}$ & $10: 00 \mathrm{am}$ & $12: 00 \mathrm{pm}$ & $2: 00 \mathrm{pm}$ & $4: 00 \mathrm{am}$ & $6: 00 \mathrm{pm}$ \\
\hline AC & $68.7 \mathrm{aA}$ & $75.5 \mathrm{bA}$ & $80.3 \mathrm{cA}$ & $83.3 \mathrm{dA}$ & $82.6 \mathrm{dA}$ & $68.3 \mathrm{aA}$ \\
BA & $68.6 \mathrm{aA}$ & $75.4 \mathrm{bA}$ & $79.7 \mathrm{cA}$ & $81.9 \mathrm{dA}$ & $82.6 \mathrm{dA}$ & $68.1 \mathrm{aA}$ \\
BAP & $68.4 \mathrm{aA}$ & $75.1 \mathrm{bA}$ & $80.0 \mathrm{cA}$ & $82.6 \mathrm{dA}$ & $83.6 \mathrm{dA}$ & $68.3 \mathrm{aA}$ \\
FB & $68.3 \mathrm{aA}$ & $75.3 \mathrm{bA}$ & $80.7 \mathrm{cA}$ & $84.1 \mathrm{~dB}$ & $83.4 \mathrm{dA}$ & $68.4 \mathrm{aA}$ \\
FBP & $68.7 \mathrm{aA}$ & $75.3 \mathrm{bA}$ & $80.0 \mathrm{cA}$ & $83.7 \mathrm{dA}$ & $82.7 \mathrm{dA}$ & $68.0 \mathrm{aA}$ \\
External & $78.2 \mathrm{bB}$ & $82.3 \mathrm{cB}$ & $85.4 \mathrm{~dB}$ & $85.8 \mathrm{~dB}$ & $81.1 \mathrm{cA}$ & $67.9 \mathrm{aA}$ \\
\hline
\end{tabular}

AC - Asbestos cement tiles, BA - Bamboo tiles, BAP - Bamboo tiles painted in white, FB - Vegetable fiber tiles and bitumen, FBP Vegetable fiber tiles and bitumen painted in white, External - Environment outside the shelters. *Different lower case letters, at the rows, differ statistically by Scott Knott test, at $1 \%$ probability. **Different upper case letters, at the columns, differ statistically by Scott Knott test, at $1 \%$ probability.

The behavior of BGHI in the treatments was the same, presented the highest values at 2:00 pm and 4:00 pm, and the lowest values at 8:00 am and 6:00 pm, which are the coolest times of the day due to low solar radiation. In a study of thermal indexes in facilities for laying hens in northeastern Brazil, JACOMÉ et al. (2007) found that the BGHI in sheds with asbestos cement roof tended to rise until 2:00 pm and then decreased. Similar results were observed in AC, FB, FBP treatments and external environment in this study. In houses with ceramic tile roof, the same authors observed increasing behavior of the values of BGHI until 4:00 pm, and this behavior is similar to that observed in the BA and BAP treatments in this study.

There were significant differences $(\mathrm{P}<0.01)$ among treatments at 2:00 pm, and the treatment that showed the highest value of BGHI was FB (84.1), this value being similar to that found in the external environment exposed to direct sunlight. This fact shows the inefficiency of FB treatment in reducing external environmental factors, damaging the thermal comfort of the facility. According to SARMENTO et al. (2005), values of BGHI up to 77 do not influence on bird development, but values between 78 and 80.5 implicate directly in the development of broilers. Thus, all treatments in this study had values above the limit of thermal comfort, considering that from 12:00 pm to 4:00 pm all treatments presented values of BGHI above 77, characterizing a state of alert, which would compromise the development of birds. In other times, there were no significant differences among treatments, being observed only difference between the treatments and the external environment exposed to direct sunlight.

Until 2:00 pm, the BGHI of all treatments remained below the BGHI observed in the external environment (exposed to sunlight), which proves that the coverage is responsible for increasing the thermal comfort situation at a facility. After the 2:00 pm, the external BGHI reduced quickly, staying for a period of time less than the BGHI observed in all treatments. It was also found that the treatment which showed a better efficacy in reducing the BGHI was BA.

There were significant differences $(\mathrm{P}<0.01)$ in BGHI values throughout the day (Table 4) in all treatments. At 2:00 pm, FB and FBP treatments showed maximum values of THL, 591.2 and 594.8 respectively, with values remaining high until 4:00 pm, time at which the THL values in these treatments did not differ from the values found at 2:00 pm. In the other treatments, the THL showed maximum value at 4:00 pm, AC (627.0), BA (609.0) and BAP (618.5).

The THL behavior observed in this study is similar to that seen by JACOMÉ et al. (2007), which found that sheds with ceramic tile roof the THL showed a growing behavior until 4:00 pm, however, this behavior differed from the behavior observed by the same authors in sheds with asbestos cement roof, where the THL showed a growing behavior until 2:00 pm, decreasing thereafter. 
TABLE 4. Mean values of THL $\left(\mathrm{W} \mathrm{m}^{-2}\right)$, in different treatments and times of collection.

\begin{tabular}{ccccccc}
\hline \multirow{2}{*}{ Treatments } & \multicolumn{7}{c}{ Times } \\
\cline { 2 - 7 } & $8: 00 \mathrm{am}$ & $10: 00 \mathrm{am}$ & $12: 00 \mathrm{pm}$ & $2: 00 \mathrm{pm}$ & $4: 00 \mathrm{pm}$ & $6: 00 \mathrm{pm}$ \\
\hline AC & $451.0 \mathrm{aA}$ & $501.0 \mathrm{bA}$ & $554.3 \mathrm{cA}$ & $579.0 \mathrm{cA}$ & $627.0 \mathrm{dA}$ & $441.5 \mathrm{aA}$ \\
$\mathrm{BA}$ & $453.2 \mathrm{aA}$ & $504.2 \mathrm{bA}$ & $552.4 \mathrm{cA}$ & $565.4 \mathrm{cA}$ & $609.0 \mathrm{dA}$ & $439.6 \mathrm{aA}$ \\
BAP & $450.0 \mathrm{aA}$ & $499.7 \mathrm{bA}$ & $549.5 \mathrm{cA}$ & $576.5 \mathrm{cA}$ & $618.5 \mathrm{dA}$ & $442.4 \mathrm{aA}$ \\
FB & $447.7 \mathrm{aA}$ & $497.8 \mathrm{bA}$ & $556.7 \mathrm{cA}$ & $591.2 \mathrm{dA}$ & $605.5 \mathrm{dA}$ & $442.5 \mathrm{aA}$ \\
FBP & $452.0 \mathrm{aA}$ & $502.6 \mathrm{bA}$ & $554.6 \mathrm{cA}$ & $594.8 \mathrm{dA}$ & $612.1 \mathrm{dA}$ & $440.5 \mathrm{aA}$ \\
External & $575.7 \mathrm{bB}$ & $623.3 \mathrm{cB}$ & $677.8 \mathrm{~dB}$ & $681.1 \mathrm{~dB}$ & $590.8 \mathrm{bA}$ & $429.9 \mathrm{aA}$ \\
\hline
\end{tabular}

AC - Asbestos cement tiles, BA - Bamboo tiles, BAP - Bamboo tiles painted in white, FB - Vegetable fiber tiles and bitumen, FBP Vegetable fiber tiles and bitumen painted in white, External - Environment outside the shelters. *Different lower case letters, at the rows, differ statistically by Scott Knott test, at $1 \%$ probability. **Different upper case letters, at the columns, differ statistically by Scott Knott test, at $1 \%$ probability.

FIORELLI et al. (2010), when studying different types of roofs on prototypes of poultry houses, found that the highest values of THL were found between 3:00pm and 4:00 pm. A similar result was observed by ABREU et al. (2009), who, while assessing the efficiency of the polyethylene liner in poultry houses with asbestos cement roof, observed the highest values of THL close to 2:00pm, and this behavior is similar to that observed in this study.

According to TEIXEIRA (1983), environments which THL presents values up to $498.3 \mathrm{~W} / \mathrm{m}^{2}$ are considered comfortable for birds, and values above this represent a stress situation for the animal. In this study, the only times that the THL was within the comfort range for birds were at 8:00 am and 6:00 pm, and only FB showed a value close to the limit of comfort to 10:00 am $\left(497.8 \mathrm{~W} \mathrm{~m}^{-2}\right)$, as in other schedules no treatment showed situation of thermal comfort.

According to ROCHA et al. (2010), high values of THL may be justified by the lack of any surrounding vegetation covering the soil around the installation, because, in these cases, the incident solar radiation on the soil tends to be reflected inside the facility, thereby increasing THL inside it, the vegetation surrounding this study did not cover the entire surface, increasing the reflection of sunlight to the interior of the shelter, whereas if there was vegetation around the installation, this could absorb most of the incident radiation, significantly decreasing the amount radiated into the installation.

Another factor that directly influences the thermal balance of the installation is ventilation, which is responsible for a large portion of the heat exchange of the air mass within the facility with the external environment. In the case of models completely open, this exchange is maximized, causing a more rapidly thermal equilibrium with the surrounding environment.

There was no significant difference for THL between treatments at different studied times, verifying only difference between the treatments and the external environment for all times, except for 4:00 pm and 6:00 pm, when the THL values found in the treatments did not differ from those found in external environment.

\section{CONCLUSIONS}

The vegetable fiber tiles and bitumen showed lower thermal performance when compared to other types of coverage, and in the reduced model in which it was installed there was the highest daily mean of BGHI at 2:00 pm (84.1). Although no significant difference was observed between the other roofs, it appears that bamboo coverage showed a more satisfactory thermal performance, being observed at the time of 2:00 pm (critical time) values of thermal indexes below other types of roofing, BGHI (81.9) and THL (565.4). 
Roofs evaluated did not provide an environment with thermal comfort for broilers throughout the day, necessitating the use of other devices to reduce the thermal indexes within the facilities, seeking maximum comfort for the animal and consequent maximum productivity.

\section{REFERENCES}

ABREU, P.G.; ABREU, V.M.N.; COLDEBELLA, A.; JAENISH, F.R.F.; PAIVA, D.P. Condições térmicas ambientais e desempenho de aves criadas em aviários com e sem o uso de forro. Arquivo Brasileiro de Medicina Veterinária e Zootecnia, Belo Horizonte, v.59, n.4, p.1014-1020, 2009.

BAÊTA, F. C.; SOUZA, C. F. Ambiência em edificações rurais: Conforto animal. 2.ed. Lavras: Editora UFV, 2010. 269 p.

BARBOSA FILHO, J.A.D.; VIEIRA, F.M.C.; GARCIA, D.B. ET al. Mudanças e uso das tabelas de entalpia. Piracicaba, 2007. Disponível em: <http://www.nupea.esalq.usp.br/imagens/ NovasTabelas.pdf>. Acesso: 6 jan. 2012.

BUFFINGTON, C. S.; COLLAZO-AROCHO, A.; CANTON, G. H.; PITT, D.; THATCHER, W. W.; COLLIER, R. J. Black globe humidity comfort index for dairy cows. St. Joseph: Transactions of the ASAE, 1997. (Paper, 77- 4517).

CONCEIÇÃO, M. N.; ALVES,S.P.; TELATIN JÚNIOR, A.; SILVA, I.J.O.; PIEDADE, S. M.S.; SAVASTANO JÚNIOR, H.; TONOLI,G. Desempenho de telhas de escória de alto forno e fibras vegetais em protótipos de galpões. Revista Brasileira de Engenharia Agrícola e Ambiental, Campina Grande, v.12, n.5, p.536-539, 2008.

ESMAY, M. L. Principles of animal environment. 2. ed. West Port: AVI, 1969. 325 p.

FERREIRA, D.F. SISVAR: um programa para análises e ensino de estatística. Revista Symposium, Lavras, v.6, p.36-41, 2008.

FIORELLI, J.; FONSECA, R.; MORCELI, J.A.B.; DIAS, A. Influência de diferentes materiais de cobertura no conforto térmico de instalações para frangos de corte no oeste paulista. Engenharia Agrícola, Jaboticabal, v.30, n.5, p.986-992, set./out. 2010.

JACOMÉ, I.M.T.D.; FURTADO, D.A.; LEAL, A.F.; SILVA, J.H.V.; MOURA, J.F.P. Avaliação de índices de conforto térmico de instalações para poedeiras no nordeste do Brasil. Revista Brasileira de Engenharia Agrícola e Ambiental, Campina Grande, v.11, n.5, p.527-531, 2007.

JENTZSCH, R. Estudos de modelos reduzidos destinados à predição de parâmetros térmicos ambientais em instalações agrícolas. 2002. 103 f. Tese (Doutorado em Construções Rurais e Ambiência) - Universidade Federal de Viçosa, Viçosa. 2002.

MELO, E.C.; LOPES, D.C.; CORRÊA, P.C. Grapsi - Programa computacional para o cálculo das propriedades psicrométricas do ar. Disponível em:

<http://www.ufv.br/dea/reveng/arquivos/vol12/v12n2p154-162.pdf>. Acesso em: 24 jun. 2011.

NAZARENO, A.C.; PANDORFI, H.; ALMEIDA, G.L.P.; GIONGO, P.R.; PEDROSA, E.M.R.; GUISELINI, C. Avaliação do conforto térmico e desempenho de frangos de corte sob regime de criação diferenciado. Revista Brasileira de Engenharia Agrícola e Ambiental. Campina Grande, v.13, n.6, p.802-808, 2009.

NAZARENO, A.C.; PANDORFI, H.; GUISELINI, C.; VIGODERIS, R.B.; PEDROSA, E.M.R. Bem-estar na produção de frangos de corte em diferentes sistemas de criação. Engenharia Agrícola, Jaboticabal, v.31, n.1, p-13-22, jan./fev. 2011.

OLIVEIRA, L. M. F.; JUNIOR, T. Y. Y.; FERREIRA, E.; CARVALHO, L. G.; SILVA, M. P. Zoneamento bioclimático da região sudeste do Brasil para o conforto térmico animal e humano. Engenharia Agrícola, Jaboticabal, v.26, n.3, p.823-831, set./dez. 2006. 
PICANÇO, S.M.; GHAVAMI, K. Comportamento à compressão de argamassas reforçadas com fibra vegetal da Amazônia. REM: R. Esc. Minas, Ouro Preto, v.61, n.1, p. 13-18, mar. 2008.

ROCHA, H.P.; FURTADO, D.A.; NASCIMENTO, J.W.B.; SILVA, J.H.V. Índices Bioclimáticos e Produtivos em Diferentes Galpões Avícolas no Semiárido Paraibano. Revista Brasileira de Engenharia Agrícola e Ambiental, Campina Grande, v.14, n.12, p.1330-1336, 2010.

SARMENTO, L. G. V.; DANTAS, R. T.; FURTADO, D. A.; NASCIMENTO, J. W. B.; SILVA, J. H. V. Efeito da pintura externa do telhado sobre o ambiente climático e desempenho de frangos de corte. Agropecuária Técnica, Areia, v.26, n.2, p.117-122, 2005.

SOUZA, C.F.; TINÔCO, I.F.F.; BAÊTA, F.C.; FERREIRA, W.P.M.; SILVA, R.S. Avaliação de materiais alternativos para confecção de termômetro de globo. Ciência e Agrotecnologia, Lavras, v.26, n.1, p.157-164, jan./fev. 2002.

SOUSA, P. Avicultura e clima quente: como administrar o bem estar às aves? Concórdia: Embrapa Suínos e Aves, Área de Transferência de Tecnologia, 2005.

TCPO 13. Tabela para composição de preços e orçamentos. São Paulo: PINI, 2008.

TEIXEIRA, V.H. Estudo dos índices de conforto em duas instalações de frango de corte para a região de Viçosa e Visconde do Rio Branco, MG. 1983. 62 f. Dissertação (Mestrado em Engenharia Agrícola) - Universidade Federal de Viçosa, Viçosa, 1983.

VIGODERIS, R. B. Ambiência e bem-estar em instalações zootécnicas - aplicações práticas. JORNADA UNIVERSITÁRIA DA UNIDADE ACADÊMICA DE GARANHUNS, 1., 2007. Garanhuns.

WELKER, J. S.; ROSA, A. P.; MOURA, D. J.; MACHADO, L. P.; CATELAN, F.; UTTPATEL, R. Temperatura corporal de frangos de corte em diferentes sistemas de climatização. Revista Brasileira de Zootecnia, Viçosa, v.37, n.8, p.1463-1467, 2008. 